\title{
Design and Realization of a Fuzzy Controller for Diabetes Type 1
}

\author{
Hajiba Legrara ${ }^{1}$, C.R. Srinivasan ${ }^{2, *}$, R. Srividya ${ }^{3}$ \\ ${ }^{1}$ National School of Electricity and Mechanics, ENSEM University, Morocco \\ 2 Department of Instrumentation and Control Engineering, Manipal Academy of Higher Education, \\ Manipal Institute of Technology, Manipal, India \\ ${ }^{3}$ Department of Electrical and Electronics Engineering, Manipal Academy of Higher Education, \\ Manipal Institute of Technology, Manipal, India
}

(Received 21 March 2021; revised manuscript received 15 June 2021; published online 25 June 2021)

\begin{abstract}
Nowadays, diabetes is one of the common diseases. It affects people of different ages, and it may lead to death, if it is not treated properly. There are many types of diabetes, the most common are type 1 , type 2 , and gestational diabetes. In this paper, we are going to focus on diabetes type 1 . It is when the pancreas does not produce enough insulin, and, as a consequence, blood sugar level increases. To control blood sugar level, we are going to use a PID controller and a fuzzy logic-based controller. The tuning method used for PID are Ziegler-Nichols, Cohen and Coon, and IMC. For the plant model, we are using Hovorka model, and food is chosen as the major factor that affects blood sugar level.
\end{abstract}

Keywords: Fuzzy control, Diabetes, PID controller, Hovorka model.

DOI: 10.21272/jnep.13(3).03021

PACS numbers: 43.58.Fm, 47.63.Cb, 07.05.Mh

\section{INTRODUCTION}

Diabetes is a chronic disease that occurs when blood glucose (blood sugar) level goes abnormally high. By 2030 , diabetes is expected to be one of the 7 death leading cause. Worldwide, more than 422 million people have diabetes. In MENA region 55 million adults (2079) are living with diabetes in 2019 , and this number is expected to double to 108 million by 2045 [1-5].

The sugar (glucose) in our blood comes from food we eat, and he is our main source of energy. But excessive sugar in the blood, can cause life threatening health problems. Diabetes takes various forms: type 1 , type 2 , and gestational diabetes. During food digestion, carbohydrates are decomposed into glucose that is carried by blood stream to different organs of the body. In order to make glucose goes into the organs, the beta cells of pancreas produce a hormone called insulin.

Our objective through this paper is to design fuzzy controller for diabetes type 1 . Before that we will have to define the plant model, or the mathematical model we will be based on for the study. There are various testing methods in diabetes: real time testing, experiments, and simulation. In order to improve the performance of existing systems, we need a model.

In many cases it is difficult to find one, reason for what we take virtual model. The majority of virtual models describe the system in differential equations. There are two types of patient models: Data Driven Models (DDMs) and Knowledge Driven Models (KDMs) [7]. The data driven model as its name indicates is based on the patients' data, it does not need too much to be developed, and it is easy to implement and develop control algorithm wit this model. The data driven models is also called black box model that relates inputs to outputs.

We already have the patient model and the transfer function. Based on the Hovorka model, the transfer function (TF) and the PID close-loop simulation system [3] is developed.

To find the gain parameters like $K p, K i$ and $K d$. We are going to use three tuning methods: Zeigler-Nichols, Cohen and Coon, and IMC.

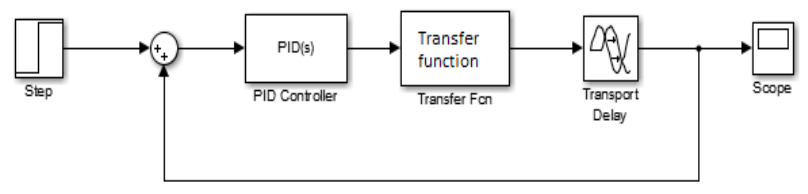

Fig. 1 - PID controller

\section{PID CONTROLLER}

\subsection{Ziegler-Nichols Closed-Loop Method}

This method is known to be the easiest one, all we need is to keep changing the gain, and observe the output on a Matlab/Simulink simulation, until we get the desired result [6].

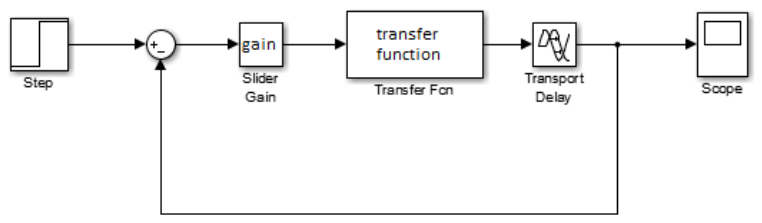

Fig. 2 - PID controller: Ziegler-Nichols closed-loop

In Matlab/Simulink we will change gain values to get best results. First, we introduce a value for proportional gain, then we raise it until we get periodic oscillations. Once we get the oscillations, we write $K_{P u}$ as the gain of the oscillations we got, and $\mathrm{Pu}$ is the period of these oscillations.

The table below shows how to calculate the PID parameters using Ziegler and Nichols. 
Table 1 - PID parameters: Ziegler-Nichols

\begin{tabular}{|c|c|c|c|}
\hline Controllers & $K p$ & $T i$ & $T d$ \\
\hline $\begin{array}{l}\mathrm{P} \\
\text { controller }\end{array}$ & $\begin{array}{l}0.5 \\
K_{P u}\end{array}$ & $\infty$ & 0 \\
\hline $\begin{array}{l}\text { PI } \\
\text { controller }\end{array}$ & $\begin{array}{c}0.45 \\
K_{P u}\end{array}$ & $\frac{P u}{1.2}$ & 0 \\
\hline $\begin{array}{l}\text { PID } \\
\text { controller }\end{array}$ & $\begin{array}{l}0.6 \\
K_{P u}\end{array}$ & $\frac{P u}{2}$ & $\frac{P u}{8}=\frac{T i}{4}$ \\
\hline
\end{tabular}

On simulation ZN PID gives the following values: $K_{P u}=300 / P u=0.55$. Therefore, by calculation using the above table we get $K p=180 ; K i=4 ; K d=16$.

\subsection{Cohen and Coon Tuning Method}

Cohen and Coon method was developed a decade after Ziegler-Nichols. This method is also based on experiment, but it is simpler to use.

In our application, we will use an open loop system and we will plot the set up and the TF. We will calculate the $g p$ as in the formula below, and then determine gain parameters $K p, K d, K i$ as in Table 2 .

$$
g p=\text { change in } \mathrm{PV} / \text { change in } \mathrm{CO}
$$

Table 2 - PID parameters: Cohen and Coon

\begin{tabular}{|l|c|c|c|}
\hline & Controller gain & Integral time & Derivative time \\
\hline $\begin{array}{l}\text { P } \\
\text { controller }\end{array}$ & $K c=\frac{1.03}{g p}\left(\frac{\tau}{t d}+0.34\right)$ & & \\
\hline $\begin{array}{l}\text { PI } \\
\text { controller }\end{array}$ & $K c=\frac{0.9}{g p}\left(\frac{\tau}{t d}+0.092\right)$ & $T i=3.33 t d \frac{\tau+0.092 t d}{\tau+2.22 t d}$ & \\
\hline $\begin{array}{l}\text { PD } \\
\text { controller }\end{array}$ & $K c=\frac{1.24}{g p}\left(\frac{\tau}{t d}+0.129\right)$ & & $T d=0.27 t d \frac{\tau-0.324 t d}{\tau+0.129 t d}$ \\
\hline $\begin{array}{l}\text { PID } \\
\text { controller }\end{array}$ & $K c=\frac{1.35}{g p}\left(\frac{\tau}{t d}+0.185\right)$ & $T i=2.5 t d \frac{\tau+0.185 t d}{\tau+0.611 t d}$ & $T i=0.37 t d \frac{\tau}{\tau+0.185 t d}$ \\
\hline
\end{tabular}

After all the calculations, we got the following values: $K p=163.4383, K i=1.15, K d=0.9945$.

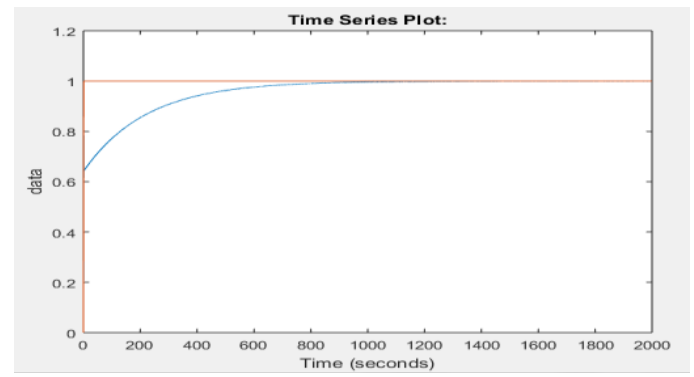

Fig. 3 - PID plot with Matlab/Simulink

\subsection{Internal Model Control (IMC)}

To use the IMC tuning method, we first have to make an approximation [1]. The given transfer function is a FODTP, it is written as

$$
g(s)=\frac{k_{p} e^{-\theta s}}{\tau_{p}+1} .
$$

We introduce $G_{c}$ as

$$
G_{c}=\frac{Q}{1-g(s) * Q} .
$$

Here $g(s)=\left(\tilde{g}_{-}\right)\left(\tilde{g}_{+}\right)$is the model, $Q=\tilde{Q} F$, $\tilde{Q}=\left(g_{-}(s)\right)^{-1}$ is the inverse of the invertible part of the model, $F=\frac{1}{(\lambda s+1)^{n}}$ is the filter factor, where $n$ is chosen to make the controller proper or semi proper. Filter factor $\lambda$ is to be adjusted. The system will perform fast if $\lambda$ has a small value.

$$
\begin{gathered}
G_{c}=\frac{\tilde{Q} F}{1-g(s) Q}, \\
G_{C}=\frac{\widetilde{Q} F}{1-\left(\tilde{g}_{-}\right)\left(\tilde{g}_{+}\right)\left(\tilde{g}_{-}\right)^{-1} F}, \\
G_{C}=\frac{\tilde{Q} F}{1-\left(\tilde{g}_{+}\right) F},
\end{gathered}
$$

then

$$
G_{C}=\frac{\left(g_{-}\right)^{-1} F}{1-\left(\tilde{g}_{+}\right) F} .
$$

As we have $g(s)=\frac{k_{p} e^{-\theta s}}{\tau_{p}+1}$, we will use Padé approximation in order to approximate the exponential term with deadtime.

Padé approximation:

$$
\begin{gathered}
e^{-\theta s}=\frac{1-\frac{\theta}{2} s}{1+\frac{\theta}{2} s}, \\
g(s)=\frac{K_{p}}{\tau_{p} s+1} * \frac{1-\frac{\theta}{2} s}{1+\frac{\theta}{2} s} .
\end{gathered}
$$

For $n=1$ we have:

$$
\begin{gathered}
G_{c}=\frac{1}{K_{p}} * \frac{\left(\tau_{p} s+1\right) *\left(\frac{\theta}{2} s+1\right)}{\left(\lambda+\frac{\theta}{2}\right) s}, \\
G_{c}=\frac{1}{K_{p}} * \frac{T_{p} \frac{\theta}{2} s^{2}+\left(\tau_{p}+\frac{\theta}{2}\right) s+2}{\left(\lambda+\frac{\theta}{2}\right) s}, \\
K_{C}=\frac{\tau_{p}+\frac{\theta}{2}}{K_{p}\left(\lambda+\frac{\theta}{2}\right)}, \tau_{I}=\tau_{p}+\frac{\theta}{2}, \tau_{D}=\frac{\tau_{p} \theta}{2 \tau_{p}+\theta},
\end{gathered}
$$

$\lambda$ will enable us to trade off robustness for different values of $\lambda$. For $\lambda=0.03, K_{c}=180.5006, \tau_{I}=0.089$, and $\tau_{D}=0.012$

\section{FUZZY LOGIC CONTROLLER}

Fuzzy logic was introduced the first time by Lotfi Zadeh in 1965, a teacher at the University of Berkeley. Later in 1970, the concept of the fuzzy logic was used for the first time. Four years later Mamdani used the concept on an industrial level [2]. Fuzzy logic imitates human ways of decision making and considering all the possibilities between digital values 0 and 1 [5]. The fuzzy controller was designed by following the standard procedure which consists of fuzzification, control rule base establishment, and defuzzification [4].

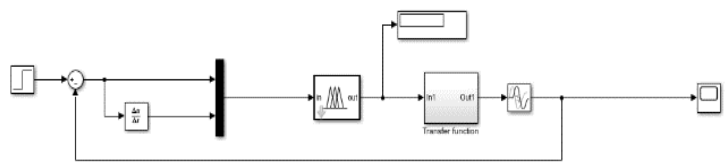

Fig. 4 - Fuzzy controller

In order to design the fuzzy logic controller, we will first define the inputs and output and their relative linguistic variables. This is the step where we need 
more data and experience of the users, the more we have the more precise our controller will be.

The next step is building membership function, writing the rule base, choosing the fuzzy inference and then defuzzification.

\subsection{Definition of Variables}

In fuzzy logic we use linguistic variables. They represent a general or common opinion, or information that most of people will understand, without requiring a specific measure system or a numerical value. In the following, we need to define linguistic variables for each input and output.

Input:

*CHO: [too_low, low, medium, high],

*Time: [simultaneous, semi_composed, high].

Output:

*Sugar level: [very_low, low, normal, medium_high, high, very_high].

Discourse universe: blood_sugar level [70-120 mg/dl].

In the tables below we associate to every linguistic variable a range of crisp value.

Table 3 - Input linguistic variables

\begin{tabular}{|c|c|c|}
\hline Input & Range & Fuzzy variable name \\
\hline \multirow{4}{*}{$\mathrm{CHO}$} & {$[-0.53-0.5319 .5]$} & Too_low \\
\hline & {$\left[\begin{array}{lllll}17.59 & 20 & 40.1]\end{array}\right.$} & Low \\
\hline & {$\left[\begin{array}{llll}40.87 & 43.8 & 59.9\end{array}\right]$} & Medium \\
\hline & {$\left[\begin{array}{lllll}59.68 & 62.08 & 105.2 & 115.4\end{array}\right]$} & High \\
\hline \multirow{3}{*}{ Time } & {$\left[\begin{array}{lllll}-11.76 & 0.2381 & 9.563\end{array}\right]$} & Simultaneous \\
\hline & {$\left[\begin{array}{lllll}5.82 & 11.8 & 14.72 & 21\end{array}\right]$} & Semi_composed \\
\hline & {$\left[\begin{array}{lllll}19.27 & 27.1 & 31.27 & 40.87\end{array}\right]$} & Composed \\
\hline
\end{tabular}

Table 4 - Output linguistic variables

\begin{tabular}{|c|c|c|}
\hline Output & Range & Fuzzy variable name \\
\hline \multirow{6}{*}{ Blood_sugar } & {$\left[\begin{array}{llllll}0 & 0 & 0.175 & 0.375\end{array}\right]$} & Very_low \\
\hline & {$\left[\begin{array}{llll}0.2804 & 0.5 & 0.788\end{array}\right]$} & Low \\
\hline & {$\left[\begin{array}{llll}0.7 & 1 & 1.254\end{array}\right]$} & Normal \\
\hline & {$\left[\begin{array}{llll}1.12 & 1.4 & 1.783\end{array}\right]$} & Medium_high \\
\hline & {$\left[\begin{array}{llll}1.66 & 2 & 2.333\end{array}\right]$} & High \\
\hline & {$\left[\begin{array}{lllll}2.24 & 2.92 & 4.058 & 4.12\end{array}\right.$} & Very_high \\
\hline
\end{tabular}

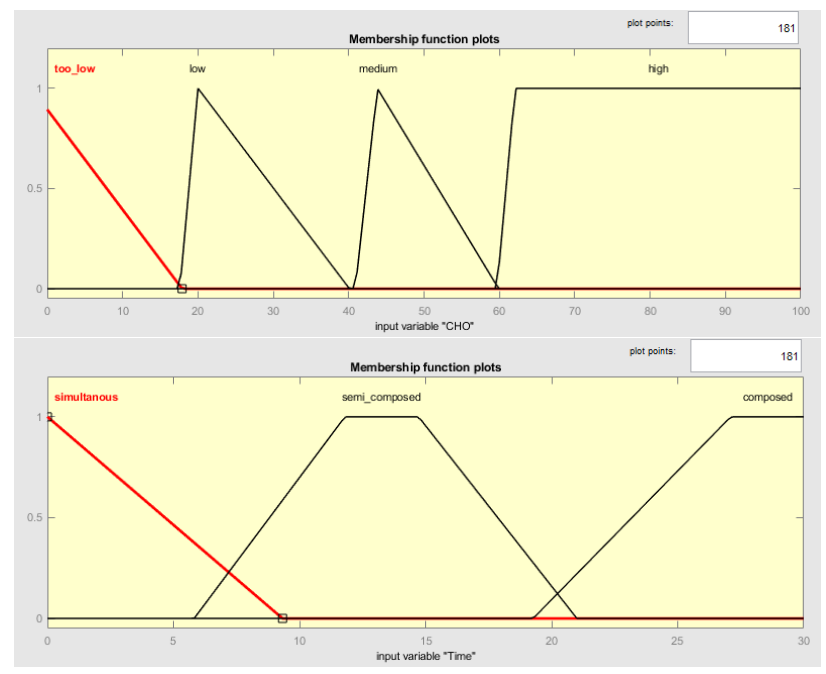

Fig. 5 - Memberships functions for input and output

\subsection{Building Membership Function}

Membership function for a fuzzy set $A$ on the universe of discourse $X$ is defined as follow:

$$
\mu_{A}: X \rightarrow[0,1],
$$

where each value of $\mathrm{X}$ is associated with a value between 0 and 1 . This value represents the degree of membership of the element in $X$ to the fuzzy set $A$.

The translation from an $x$ element of $X$ to $\mu_{A}(x)$ is called fuzzification.

A membership function can take different shapes; triangular, trapezoidal, gaussian, ..., and only experience will help us to know better which shape of membership function is good for our application.

\subsection{Fuzzy Rules}

The base Fuzzy rules are written in the form:

$$
\text { If......(condition).........then.........(result)...... }
$$

This conditional rule can be true to a degree.

The total number of rules required is 12 , and they are all shown in the table below.

Table 5 - Fuzzy rules

\begin{tabular}{|c|l|}
\hline $\mathrm{N}^{\circ}$ & Fuzzy rules \\
\hline 1 & $\begin{array}{l}\text { If (CHO is too_low) and (Time is simultaneous) } \\
\text { then (Blood_sugar is low) }\end{array}$ \\
\hline 2 & $\begin{array}{l}\text { If (CHO is medium) and (Time is simultaneous) } \\
\text { then (Blood_sugar is medium_high) }\end{array}$ \\
\hline 3 & $\begin{array}{l}\text { If (CHO is low) and (Time is simultaneous) } \\
\text { then (Blood_sugar is normal) }\end{array}$ \\
\hline 4 & $\begin{array}{l}\text { If (CHO is medium) and (Time is semi_composed) } \\
\text { then (Blood_sugar is medium_high) }\end{array}$ \\
\hline
\end{tabular}

\subsection{Defuzzification}

For the defuzzification step we choose the Centroid method. It returns the center of gravity of the fuzzy set along the $x$-axis. The centroid is calculated using the following formula, where $f(x i)$ is the membership value for point $x i$ in the universe of discourse.

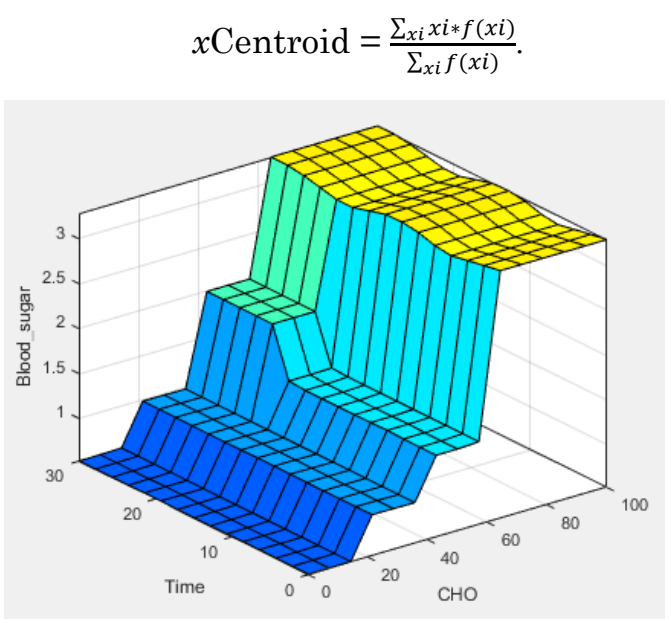

Fig. 6 - Control view 


\section{CONCLUSIONS}

This article presented an overview of PID controller, and three methods of tuning it: Zeigler-Nichols, Cohen and Coon, and IMC. Simulation results were deducted using Matlab/Simulink. An application with fuzzy logic controller was introduced, as fuzzy logic is signing a user-friendly and successful implementation since it only needs data from users or professional experience that is expressed through the rule base.

\title{
REFERENCES
}

1. M. Shamsuzzoha and M. Lee, 2006 SICE-ICASE International Joint Conference, 2485 (Busan, 2006).

2. L.A. Zadeh, Inform. Contr. 8, 338 (1965).

3. Kiam Heong Ang, G. Chong and Yun Li, IEEE Trans. Control Syst. Technol. 13 No 4, 559 (2005).

4. J. Jantzen, Design of Fuzzy Controllers (1998).

5. Kazuo Tanaka, Hua O. Wang, Fuzzy Control Systems Design and Analysis: A Linear Matrix Inequality Approach (John Wiley \& Sons, Inc.: 2001).

6. S.R. Vaishnav, Z.J. Khan, Proceedings of the World Congress on Engineering and Computer Science 2007 WCECS 2007 (San Francisco, USA: 2007).

7. C.R. Srinivasan, S. Meenatchi Sundaram, V.I. George, J. Adv. Res. Dynam. Control Syst. 10 No 06, 1238 (2018).

8. K.S. Tang, Kim Fung Man, Guanrong Chen, S. Kwong, IEEE Trans. Indust. Electron. 48 No 4, 757 (2001).

9. L.A. Zadeh, Information Sci. 8 No 3, 199 (1975).

10. S. Schmidt, D. Boiroux, A.K. Duun-Henriksen, J. Diabetes Sci. Technol. 7 No 5, 1255 (2013).

11. C. Cobelli, C. Dalla-Man, G. Sparacino, L. Magni, G. De Nicolao, B.P. Kovatchev, IEEE Rev. Biomed. Eng. 2, 5496 (2009).

12. C.R. Srinivasan, S. Shindhe, R. Srividya, J. Adv. Res. Dynamical Control Syst. 10 No6 (2018).

\section{Розробка та реалізація контролера нечіткої логіки для діабету 1 типу}

\author{
Hajiba Legrara ${ }^{1}$, C.R. Srinivasan ${ }^{2}$, R. Srividya ${ }^{3}$ \\ ${ }^{1}$ National School of Electricity and Mechanics, ENSEM University, Morocco \\ ${ }^{2}$ Department of Instrumentation and Control Engineering, Manipal Academy of Higher Education, \\ Manipal Institute of Technology, Manipal, India \\ ${ }^{3}$ Department of Electrical and Electronics Engineering, Manipal Academy of Higher Education, \\ Manipal Institute of Technology, Manipal, India
}

\begin{abstract}
$\mathrm{y}$ наш час діабет є одним із найпоширеніших захворювань. Він вражає людей різного віку і може призвести до летального результату, якщо не лікувати його належним чином. Існуе багато типів діабету, найбільш поширеними з яких є тип 1 , тип 2 та гестаційний діабет. У роботі ми сфокусуемось на діабеті типу 1. Він трапляеться, коли підшлункова залоза не виробляе достатньо інсуліну, i, як наслідок, рівень цукру в крові зростае. Для контролю рівня цукру в крові ми будемо використовувати PID контролер та контролер нечіткої логіки. Методами налаштування, які застосовуються для PID контролера, е методи Ziegler-Nichols, Cohen-Coon, та IMC. Як модель управління ми використовуемо модель Говорки, а їжа обрана головним фактором, що впливае на рівень цукру в крові.
\end{abstract}

Ключові слова: Управління засобами нечіткої логіки, Діабет, PID контролер, Модель Говорки. 